\title{
INTERNATIONAL COOPERATION OF THE MIDDLE URALS WITH THE COUNTRIES OF THE EUROPEAN UNIOIN AT THE PRESENT STAGE. THE REPUBLIC OF CYPRUS IS TAKEN AS AN EXAMPLE
}

\author{
Evgeniya Yazovskikh ${ }^{103}$ \\ Ekaterina Pazdnikova104
}

https://doi.org/10.31410/itema.2018.274

\begin{abstract}
Russia and Cyprus have always been particularly close to each other. The attitude of the Cypriots to the Russians is sincere and respectful. For several decades, these two countries have been interconnected by historical, political, business relations, which are friendly and have a significant impact on the development and cooperation of both states. Diplomatic relations between the countries, then still the USSR, were established in 1960, when Cyprus was proclaimed an independent republic. The amicable nature of bilateral relations is reflected in the identity of the views and positions of both countries on resolving major international issues, as well as the Russian support of the Republic of Cyprus on reaching a fair solution to the Cyprus issue based on UN Security Council resolutions.

The successful economic development promoted the transformation of the Republic of Cyprus into the international center of banking services and business, one of the biggest tourist resorts in the world, and the language learning center that is very popular with school children and students.

Since 2014, the General Consulate of the Republic of Cyprus has been operating in the capital of the Urals, the city of Yekaterinburg. Its activity is aimed at strengthening and developing economic, commercial, cultural, business relations, attracting tourists from the Urals to the Mediterranean island. In their speeches and meetings, representatives of the Consulate General always note the attractiveness of Cyprus, and also focus on its competitive advantages compared to other countries.
\end{abstract}

Keywords: international cooperation, development prospects, foreign trade, tourism, services, investments

\section{Introduction}

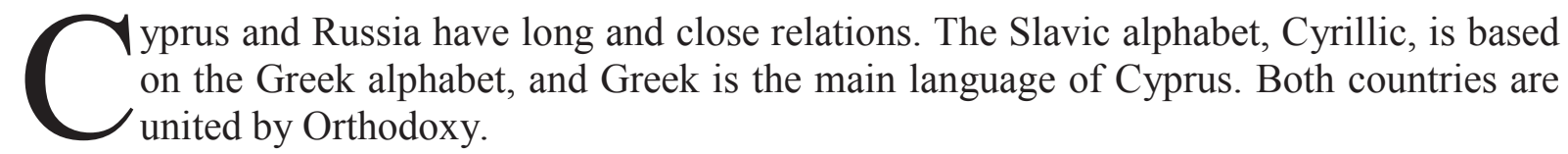

Diplomatic relations between the countries, then still the USSR, were established in 1960, when Cyprus was proclaimed an independent republic.

The friendly nature of bilateral relations is reflected in the identity of the views and positions of both countries on resolving major international issues, as well as the Russian support of the Republic of Cyprus on reaching a fair solution to the Cyprus issue based on UN Security Council resolutions.

\footnotetext{
${ }^{103}$ Ural federal University named after the first President of Russia B.N.Yeltsin, Russia

${ }^{104}$ Ural federal University named after the first President of Russia B.N.Yeltsin, Russia
} 
The attitude of the Cypriots to the Russians has always been and remains sincere and respectful.

\section{Discussion and Results}

The locals and visitors often call Cyprus as an island of love. In recent years, it has become one of the most popular resorts visited by Russian tourists all year round. Statistics for the period from 2005 to 2014 (tables 1 and 2) clearly shows that the number of Russians who visited Cyprus was many times higher than the number of foreign tourists vacationing in the Republic during the same period [1].

Table 1 - The number of Russian tourists served by tourist firms (thousand people)

\begin{tabular}{|l|c|c|c|c|c|c|}
\hline & \multicolumn{7}{|c|}{ Years } \\
\cline { 2 - 7 } & $\mathbf{2 0 0 5}$ & $\mathbf{2 0 1 0}$ & $\mathbf{2 0 1 1}$ & $\mathbf{2 0 1 2}$ & $\mathbf{2 0 1 3}$ & $\mathbf{2 0 1 4}$ \\
\hline $\begin{array}{l}\text { Total Russian tourists in different } \\
\text { countries }\end{array}$ & 4396,3 & 8203,9 & 8023,7 & 8942,2 & 9883,0 & 8487,1 \\
\hline Cyprus & 15,0 & 45,9 & 80,2 & 122,5 & 153,7 & 109,6 \\
\hline
\end{tabular}

Table 2 - The number of foreign tourists served by tourist firms (thousand people)

\begin{tabular}{|l|c|c|c|c|c|c|c|}
\hline & \multicolumn{7}{|c|}{ Years } \\
\cline { 3 - 8 } & & $\mathbf{2 0 0 5}$ & $\mathbf{2 0 1 0}$ & $\mathbf{2 0 1 1}$ & $\mathbf{2 0 1 2}$ & $\mathbf{2 0 1 3}$ & $\mathbf{2 0 1 4}$ \\
\hline $\begin{array}{l}\text { Total Russian } \\
\text { countries }\end{array}$ & tourists in different & 678,2 & 225,9 & 263,9 & 236,8 & 348,5 & 291,9 \\
\hline Cyprus & & 0,1 & 0,1 & 0,9 & 1,0 & 0,9 & 0,0 \\
\hline
\end{tabular}

According to the survey of tourist companies' employees, such a popularity of Cyprus with Russian tourists can be explained by the following reasons:

First - the mild climate on the island, low air temperature, the predominance of sunny and warm days, rare and intermittent rain.

Second - safety in any place of the island at any day time; the absence of wars and political conflicts in the region, any violation is punished by strict laws.

Third - good hotel service, various entertainment activities, shops for customers with different financial opportunities.

Fourth - the versatility of rest: beach holidays, visits to spa salons, walks in the mountains, sightseeing, sightseeing trips, varied and unique cuisine in restaurants and cafes and etc.

Fifth - the ideal sea for diving, a lot of scuba diving clubs, opportunities for water skiing, mountain skiing, sailing, windsurfing, golf, tennis, horseback riding, jeep safari.

Sixth - the island is an open-air museum, where tourists have a unique opportunity to visit ancient Orthodox churches and ruins, minarets and monasteries, Roman amphitheaters, castles, luxurious Venetian palaces and etc.

Seventh - Cyprus is a family holiday, especially with small kids, providing: clean beaches, safe waterslides for children, shallow depth along the coast, professional animators, competitions, 
games, concerts, clubs, children's menu in restaurants and hotels, a large range of children's products in stores and shopping centers.

Eighth - the absence of a language barrier, because Cypriots perfectly know English, communicate with tourists with pleasure; Russian residents who own real estate, businesses, and also work in Cyprus communicate with compatriots in their native Russian language.

Ninth - the popularity of eco-tourism, which provides a unique opportunity to live in villages in traditional Cypriot conditions, officially supported by the Government of Cyprus.

Tenth - visa-free entry into the country, which today is of great importance for tourists when choosing a place to rest.

Another confirmation of Cyprus popularity among Russians is the fact that over the past five years, the island has become one of the ten most visited countries in the world. Priority was given to Egypt, Turkey, Germany (table 3) [2]. As employees of travel agencies say, Cyprus has "its tourists" that is connected with good service and rest at a high competitive level.

Table 3 - Abroad trips made by Russians tourists 2015 - 2011 (thousand trips)

\begin{tabular}{|l|l|c|c|c|c|c|c|}
\hline \multirow{2}{*}{ № } & \multirow{2}{*}{ Country } & \multicolumn{7}{|c|}{ Years } \\
\cline { 3 - 8 } & & $\mathbf{\%}$ by 2014 & $\mathbf{2 0 1 5}$ & $\mathbf{2 0 1 4}$ & $\mathbf{2 0 1 3}$ & $\mathbf{2 0 1 2}$ & $\mathbf{2 0 1 1}$ \\
\hline 1. & Egypt & $-13,4$ & 1054,6 & 1218,0 & 1177,9 & 803,9 & 488,6 \\
\hline 2. & Turkey & $-25,7$ & 1031,5 & 1387,8 & 1212,9 & 936,4 & 1132,7 \\
\hline 3. & Germany & $-29,6$ & 284,2 & 404,0 & 413,4 & 334,6 & 324,4 \\
\hline 4. & Thailand & -53 & 255,9 & 545,5 & 570,7 & 458,5 & 421,2 \\
\hline 5. & Italy & -35 & 234 & 358,6 & 346,8 & 265,0 & 262,0 \\
\hline 6. & Spain & -43 & 233,6 & 410,3 & 401,9 & 291,7 & 237,3 \\
\hline 7. & UAE & -46 & 185,4 & 345,0 & 346,7 & 265,3 & 188,0 \\
\hline 8. & Greece & $-53,5$ & 176,8 & 380,1 & 399,7 & 203,7 & 201,0 \\
\hline 9. & China & $-56,6$ & 156,4 & 360,4 & 484,2 & 572,7 & 631,8 \\
\hline 10. & Cyprus & -31 & 150 & 217 & 213,8 & 140 & 123,4 \\
\hline & Total: & $-33,8$ & 5489,3 & 8293,0 & 8522,6 & 6473,2 & 6069,7 \\
\hline
\end{tabular}

In 2016 the situation has changed in the tourist market of Russia. Countries waiting for the Russians at their resorts (Egypt and Turkey) were closed for political reasons; so many Russian tourists spent their holidays inside the country, visited neighboring countries or rested in other states.

As for Cyprus, the island entered the top ten most visited places by Russians again by the number of tourist trips (table 4).

Table 4 - Number of tours abroad in 2016 (thousands)

\begin{tabular}{|l|l|c|c|c|c|}
\hline \multirow{2}{*}{ No } & \multirow{2}{*}{ Total: } & \multicolumn{4}{|c|}{ Years } \\
\cline { 3 - 6 } & From them to the countries: & \% by 2015 & $\mathbf{2 0 1 6}$ & $\mathbf{2 0 1 5}$ & $\mathbf{2 0 1 4}$ \\
\cline { 3 - 6 } & & -8 & 31659 & 34390 & 42921 \\
\hline 1. & Abkhazia & 11,3 & 4257 & 3824 & 3282 \\
\hline 2. & Finland & $-5,6$ & 2894 & 3067 & 4283 \\
\hline 3. & Kazakhstan & $-8,8$ & 2850 & 3125 & 3330 \\
\hline
\end{tabular}




\begin{tabular}{|l|l|c|c|c|c|}
\hline 4. & Ukraine & 8,8 & 1804 & 1657 & 2558 \\
\hline 5. & China & 30,5 & 1676 & 1284 & 1731 \\
\hline 6. & Estonia & 2,3 & 1511 & 1477 & 1775 \\
\hline 7. & Poland & $-16,5$ & 1104 & 1322 & 1608 \\
\hline 8. & Germany & $-4,9$ & 1057 & 1111 & 1435 \\
\hline 9. & Thailand & 28,4 & 867 & 675 & 1250 \\
\hline 10. & Cyprus & 47,8 & 813 & 550 & 670 \\
\hline
\end{tabular}

Moreover, the table shows that the tourist flow to Cyprus in 2016 increased by $47,8 \%$ compared with the previous year and amounted to over 800 thousand people. According to the data of travel agencies, Cyprus was recognized as the most popular destination visited by Russian tourists on May holidays.

The Statistical Service of Cyprus "Cystat" also shows some interesting data. Thus, 2016 was the record-breaking year when the number of tourists visiting the island was more than 3 million people, which is almost $20 \%$ more than in 2015 .

Cypriots explain such an increase in tourists' interest to the island by cheap euro, a stable and safe political situation in the country at that time. The largest number of tourists who came to Cyprus in 2016 were residents of the UK, followed by tourists from Russia, Greece and Germany. In 2017, the increase in flow to Cyprus tourist sector continued [3].

Currently, economic and trade relations between Russia and Cyprus are at a high level, that can be confirmed by figures in table 5 .

Table 5 - Trade between the Russian Federation and foreign countries, million US dollars

\begin{tabular}{|c|c|c|c|c|c|c|c|c|c|c|}
\hline & \multicolumn{5}{|c|}{ Export } & \multicolumn{5}{|c|}{ Import } \\
\hline & \multicolumn{5}{|c|}{ Years } & \multicolumn{5}{|c|}{ Years } \\
\hline & 2000 & 2010 & 2014 & 2015 & 2016 & 2000 & 2010 & 2014 & 2015 & 2016 \\
\hline Total & 89269 & 337467 & 433173 & 393512 & 285674 & 22276 & 197184 & 253776 & 182902 & 182267 \\
\hline $\begin{array}{c}\text { Countries } \\
\text { of EC }\end{array}$ & 36893 & 211469 & 258537 & 165581 & 130667 & 11144 & 95518 & 118499 & 70194 & 69878 \\
\hline Cyprus & 1722 & 1641 & 610 & 244 & 283 & 35,5 & 27,0 & 48,6 & 59,2 & 12,7 \\
\hline $\begin{array}{c}\text { Other } \\
\text { countries }\end{array}$ & 52376 & 125998 & 174636 & 227931 & 155007 & 11132 & 101666 & 135227 & 112708 & 112389 \\
\hline
\end{tabular}

According to the data of the report on foreign trade between Russia and Cyprus, in 2016 the trade turnover increased by $10,34 \%$ compared with 2015 . Russia's exports to the economy of the Republic of Cyprus increased by 15,94\% compared with 2015, while Russia's imports from Cyprus, on the contrary, decreased by $12,73 \%$ compared with the same period.

As for the share of Cyprus in the foreign trade turnover of Russia in 2016, it amounted to $0,0715 \%$ versus $0,0576 \%$ compared with the previous year, thus Cyprus took the 83 rd place (against 87 place in 2015) in the Russian trade share in 2016.

The share of the Republic in Russia's exports in 2016 amounted to 0,0991\% against 0,0710\% in 2015 and in terms of the share in Russian exports in 2016, Cyprus took 73rd place (against 
79 in 2013). And the share of Cyprus in Russian imports (91st place against 88th place in 2015) was $0,0283 \%$ versus $0,0324 \%$ in 2015 .

Cyprus imports from Russia mainly oil, ferrous and non-ferrous metals, wood, etc. In its turn, the Republic supplies citrus fruits, pharmaceutical products and food products to Russia [4].

In recent years, the Republic of Cyprus has attracted an increasing number of Russian businessmen. Successful economic development contributes to transforming the country into an international center for banking services and business. In addition, Cyprus is an excellent base for investments, in particular direct, as well as for developing various business activities. Table 6 shows that Cyprus is a leader in attracting direct investments from Russia among the largest recipient countries of direct investments [5].

Table 6 - Direct investments from Russia into the economy of the countries largest recipients of direct investments, million US dollars

\begin{tabular}{|c|c|c|c|}
\hline Total direct investments. & $\mathbf{2 0 1 4}$ & $\mathbf{2 0 1 5}$ & $\mathbf{2 0 1 6}$ \\
\cline { 2 - 4 } From them to the countries: & 57082 & 22085 & 22314 \\
\hline Cyprus & 23546 & 4249 & 9827 \\
\hline Virgin Islands (UK) & 718 & 3301 & 1795 \\
\hline Switzerland & 6927 & 203 & 1433 \\
\hline The Bahamas & 756 & 1054 & 1205 \\
\hline Turkey & 1183 & 1475 & 1184 \\
\hline Ireland & 91 & 479 & 1139 \\
\hline Singapore & 817 & 383 & 888 \\
\hline USA & 1654 & 819 & 873 \\
\hline The Netherlands & 2132 & 461 & 841 \\
\hline
\end{tabular}

The growth of foreign exchange, political instability in the world, the criminal situation in a number of countries and many other factors resulted in Russian tourists' giving greater preference to rest inside their country in the period from 2010 to 2016 (table 7) [6].

Table 7 - The number of Russian tourists sent by travel agencies in tours of Russia and foreign countries

\begin{tabular}{|c|c|c|c|c|c|c|c|c|}
\hline & \multicolumn{2}{|c|}{$\mathbf{2 0 1 0}$} & \multicolumn{2}{c|}{$\mathbf{2 0 1 4}$} & \multicolumn{2}{c|}{$\mathbf{2 0 1 5}$} & \multicolumn{2}{c|}{$\mathbf{2 0 1 6}$} \\
\cline { 2 - 9 } & $\begin{array}{c}\text { number, } \\
\text { thousand } \\
\text { people }\end{array}$ & $\begin{array}{c}\%, \text { to } \\
\text { total } \\
\text { number }\end{array}$ & $\begin{array}{c}\text { number, } \\
\text { thousand } \\
\text { people }\end{array}$ & $\begin{array}{c}\%, \text { to } \\
\text { total } \\
\text { number }\end{array}$ & $\begin{array}{c}\text { number, } \\
\text { thousand } \\
\text { people }\end{array}$ & $\begin{array}{c}\%, \text { to } \\
\text { total } \\
\text { number }\end{array}$ & $\begin{array}{c}\text { number, } \\
\text { thousand } \\
\text { people }\end{array}$ & $\begin{array}{c}\%, \text { to } \\
\text { total } \\
\text { number }\end{array}$ \\
\hline Total & 8203,9 & 100 & 8487,1 & 100 & 7889,2 & 100 & 6706,3 & 100 \\
\hline Russia & 1741,0 & 21,22 & 1974,2 & 23,26 & 2628,2 & 33,3 & 3284,2 & 48,97 \\
\hline Cyprus & 45,9 & 0,6 & 109,6 & 1,3 & 123,5 & 1,56 & 224,4 & 3,34 \\
\hline
\end{tabular}

For years, the Republic of Cyprus has been actively developing cooperation with individual regions of the Russian Federation. Thus, since 2014, the Consulate General of Cyprus has been operating in the capital of the Urals, Yekaterinburg. One of its functions is to promote Cyprus as a resort and a place of investments, as well as the development of economic, scientific and cultural ties between Cyprus and Sverdlovsk region.

In November 2015 at the meeting with the Governor of Sverdlovsk Region, the General Consul of the Republic of Cyprus in Yekaterinburg noted that "Cyprus and Sverdlovsk region have good relations and a steady flow of tourists. Cyprus and Yekaterinburg are connected by direct regular flights and thousands of Ural citizens come to the island during the tourist season. Now 
we are actively working at all year round flights from Yekaterinburg to Cyprus since there is a demand for these flights, and it is quite high." [7]. Today there are regular charter flights from the Urals to Cyprus. In particular, the "North Wind" and "Ural Airlines" fly to the island three times a week, the airline "Russia" - five times.

The vast majority of travel companies and tour operators in the region work with the resort cities of Cyprus. Such operators as: "Coral Travel", "Teztour", "Pegas Touristic", "BiblioGlobus", "Intourist" and others are the most popular with the Ural tourists.

In April 2016 the consulate took part in the exhibition LETO-2016, organized and held at the exhibition center "EKATERINBURG EXPO".

In May 2016 the consul attended an event dedicated to the start of direct flights to Cyprus from Yekaterinburg, where he expressed his gratitude to everyone who helped to organize the rest of Russian tourists in Cyprus.

In August 2016 the Consul General visited Tyumen with the aim of arranging the tourist forum to attract participants from other cities located in the consular district and inviting heads of local tour offices to take part in it.

In October 2016 a tourist forum "Cyprus: alternative tourism" was held in Yekaterinburg, where residents of the city and region were presented with new tourist opportunities of Cyprus. Besides, two photos - exhibitions: "The World Heritage of Cyprus: History, Myth and Religion" and "People and the Earth" were organized by the Consulate, also with the aim of attracting attention and interest to the country.

In the same month, the Consulate General in Yekaterinburg took part in the EXPOTRAVEL2016 exhibition, which was held at the EKATERINBURG EXPO Exhibition Center, as well as in a mini-seminar devoted to tourism in Cyprus in winter.

Thus, the Consulate General of the Republic of Cyprus in Yekaterinburg is actively working at attracting Ural tourists to the Mediterranean Sea Island. In his speeches and meetings, the consul repeatedly pointed out the attractiveness of the island, the willingness to receive and serve tourists, focused on the competitive advantages of Cyprus compared to other countries.

One can also quote his words in an interview: "The growth of the exchange rate directly affects prices of the tourist market. Perhaps new prices will reduce the flow of Russian tourists to Cyprus, but nothing doing. What we are trying to do is to keep prices at the same level, and maybe even lower. Unlike Turkey, we have a more developed tourism system. Yes, we cannot compete in price, but we are trying to surpass Turkey in quality of services. We hope that the effect will be less severe than it is predicted today, and many Russians will rest in Cyprus. I think that they will get interested in nature, mountains and atmosphere of the region. Some large travel companies sending tourists to Cyprus, consider possibilities of inbound tourism from Cyprus to Sverdlovsk region" [3].

The question of inbound tourism in the Urals in general, and in Sverdlovsk region, in particular, is interesting and important. Tourism is necessary for the historical, political, economic, educational, cultural development of regions.

For many years, the Middle Urals was closed to foreign tourists. Recently, more and more people from different parts of the world come to the region to discover interesting historical 
facts, enjoy regional nature, and make a pilgrimage to holy places. But as a mass phenomenon, foreign inbound tourism in the Middle Urals is a matter for future.

Active cooperation between Russia and Cyprus is observed in the field of economy, business, international relations, etc. Thus, in November 2015, a business forum was held at the Ural Chamber of Commerce and Industry: "Cyprus and Russia: New Opportunities for Business Cooperation". Its purpose was to develop bilateral trade, economic and investment relations, attract Russian investors and entrepreneurs to cooperate with Cyprus enterprises.

Despite this, it is important to note that today the Republic of Cyprus is not one of the main foreign trade partners of Sverdlovsk region. A significant contribution of the region to the foreign trade was made by Cyprus until 2002, when turnover reached $\$ 17 \mathrm{mln}$, then the volume of trade relations significantly decreased. According to the Ural Customs Administration, at the end of 2016, the foreign trade turnover of Sverdlovsk region and the Republic of Cyprus amounted to $\$ 41$ thousand, all exports. In the first half of 2017, export deliveries increased by more than 3 times, but no import deliveries were made (table 8).

Table 8 - Indicators of foreign trade of the Sverdlovsk region with the Republic of Cyprus

2012-2016

\begin{tabular}{|c|c|c|c|c|c|c|}
\hline \multirow[b]{2}{*}{ Years } & \multicolumn{3}{|c|}{ Turnover } & \multirow{2}{*}{$\begin{array}{l}\text { Exports, } \\
\text { thous. } \\
\text { US dollars }\end{array}$} & \multirow{2}{*}{$\begin{array}{l}\text { Import, } \\
\text { thous. US } \\
\text { dollars }\end{array}$} & \multirow{2}{*}{$\begin{array}{l}\text { Balance, thous. } \\
\text { US dollars }\end{array}$} \\
\hline & $\begin{array}{c}\text { thous. US } \\
\text { dollars }\end{array}$ & place & share $\%$ & & & \\
\hline 2012 & 14 & 128 & 0,00 & 14 & 0 & 114 \\
\hline 2013 & 0 & - & 0 & 0 & 0 & 0 \\
\hline 2014 & 3031 & 81 & 9,03 & 0 & 3031 & -3031 \\
\hline 2015 & 522 & 93 & 0.01 & 518 & 4 & 515 \\
\hline 2016 & 41 & 112 & 0,00 & 41 & 0 & 41 \\
\hline
\end{tabular}

In 2015, Sverdlovsk region exported mainly chemical products to the Republic of Cyprus, and imported engineering products. In 2016, mineral products and metals were added to the export of chemical products to the Republic of Cyprus; no imports were made. In the first half of 2017, export growth was mainly due to supplies of printing products and wood, while there were no deliveries of chemical products, and imports were not resumed either [8].

Unlike indicators of foreign trade, international cooperation in many areas between Sverdlovsk region and the Republic of Cyprus is rapidly growing. In July 2016, an Agreement on cooperation between the administration of Polevskoy (Sverdlovsk region, RF) and Cannavia (the Republic of Cyprus) was signed. In September of the same year, the Agreement on twin relations between Revda (Sverdlovsk region, RF) and Kato Pyrgos Tillirias (Republic of Cyprus) was signed [9].

The development of friendly relations and strengthening cooperation between Sverdlovsk region and Cyprus are facilitated by the so-called "no-tie" meetings. Thus, in July 2017 in the residence of Sverdlovsk region Governor, the opening of the exhibition "Russian artists paint Cyprus" was held. This project was implemented in the framework of strengthening twin relations of the Cyprus city of Kannavia and the town of Polevskoy, Sverdlovsk Region.

And in January 2018, for the fifth time, the team of the Consulate General of the Republic of Cyprus took part in an international bowling tournament among diplomatic and trade missions of foreign countries accredited in Yekaterinburg. Representatives of the General Consulate 
consider that sport unites people; therefore such events contribute to the development of friendly relations between states [10].

In October 2017, a meeting of the heads of municipalities of the Republic of Cyprus with the heads of municipalities of Sverdlovsk region was held at the Ministry of International and Foreign Economic Relations of Sverdlovsk region. During the meeting, issues of cooperation in such areas as small and medium business, scientific, technical and educational work, the implementation of research and educational programs, exchange programs for students, exhibitions and other problems were discussed. [8].

In March 2017, the World Trade Center of Cyprus and Delfi Partners held the largest real estate conference, the purpose of which was to stimulate interest in investing in the Cyprus real estate sector and promote Cyprus as an attractive regional real estate investment center.

The official partners of the conference were the Cyprus Chamber of Commerce and Industry, the Organization for the Promotion of Tourism in Limassol, the Cyprus Investment Agency and the Association of Large Investment Projects. This conference was also attended by businessmen, investors and entrepreneurs from Sverdlovsk region and the city of Yekaterinburg [11].

In March 2018, Cyprus President N. Anastasiadis assessed the prospects for holding the World Exhibition EXPO 2025 in the capital of the Urals, stating: "We have excellent relations in our political, economic, and cultural fields, which we would like to develop further. I think that EXPO-2025 can help us in it." The exhibition is defined as: "Transforming the world: innovation is better life for future generations" and it covers the following aspects: the impact of innovation on the environment, technology, education, health, human well-being, economy, etc., as well as attracting innovations for developing Yekaterinburg, Sverdlovsk region and the world [12].

In April 2018, the tour operator "Biblio-Globus" with the participation of representatives of Cyprus well-known hotel chains organized an event for Yekaterinburg tourist community dedicated to beginning the summer season in Cyprus. The business breakfast was attended by representatives of the Consulate General of the Republic of Cyprus in Yekaterinburg, as well as the Cyprus Tourism Organization.

Another event, also held in April 2018 at the exhibition center EKATERINBURG EXPO, was the participation of the General Consulate of the Republic of Cyprus in the exhibition LETO2018, during which visitors of the exhibition got answers to all their questions on history of Cyprus, its sights and places for rest. Among the regular exhibitors were leading travel companies, the largest tour operators in Russia, representatives of foreign countries, airlines and hotels, insurance companies, banks, and the tourist press [11].

\section{Conclusion}

Thus, international cooperation between Russia, on the whole, and Sverdlovsk region, in particular, and the Republic of Cyprus is manifested in all spheres of life. The Consulate General of Cyprus in Yekaterinburg is actively working to establish, strengthen and develop economic, commercial, cultural, business relations, attracting tourists from the Urals to the Mediterranean island. In their speeches and meetings, representatives of the Consulate General 
have always noted the attractiveness of Cyprus, and also focus on its competitive advantages compared to other countries.

\section{References}

1. Russian statistical yearbook. 2015: Stat.sb./ Rosstat. Moscow, 2015. S. 257-258.

2. Compiled by a survey of travel companies.

3. Statistics Service of Cyprus [Electronic resource]. URL: http: //www.analysis/ kipros.ru/

4. URL:http:// Russian trade.com

5. Russian statistical yearbook. 2017: Stat.sb./ Rosstat. Moscow, 2017. P. 307.

6. Russian statistical yearbook. 2017: Stat.sb./ Rosstat. Moscow, 2017. P. 238.

7. Russia and Cyprus: partnership in the sphere of economy, education and tourism [Electronic resource]. URL: http: //www.oblgazeta.ru/ economics / 20958

8. URL: http://oblgazeta.ru

9. URL: http://Uralimsttur.ru

10. URL: http://mfa.gov.cy

11. URL:http://kyp.rs.gov.ru

12. URL://http://totalexpo.ru 